\title{
DEFINITENESS STRATEGIES AND WORD ORDER IN EXISTENTIAL-LOCATIVES AND LOCATIVES IN LATE AND VULGAR LATIN
}

\section{O. INTRODUCTION}

$\S 1$. The parameters which began to undergo a profound change in Late Latin include the marking of definiteness and the gradual fixation of a different word order. ${ }^{1}$ These two phenomena are brought into connection by M. Durante's observation $(1981,62)$ that article development ${ }^{2}$ is one of the main agents involved ${ }^{3}$ in the emergence of a fixed order of constituents.

$\S 2$. The two parameters are still subject to investigation. The discussion of definiteness markers focuses on how and when precisely the article appeared, but it has yielded contradictory conclusions: while some scholars acknowledge the existence of articles in Late and Vulgar Latin texts, such as Egeria's Peregrinatio,${ }^{4}$ others deny it. ${ }^{5}$ In addition, there are some less extreme views arguing for an intermediate stage in the long evolution from demonstratives to articles in Late Latin texts. ${ }^{6}$

The research on word order, especially in Late Latin, frequently focuses on the position of the elements considered basic in the language; ${ }^{7}$ thus, generally speaking, almost everyone is agreed on the $\mathrm{SOV}>\mathrm{SVO}^{8}$ change, although an alternation of the two orders can be established for the Classical as well as for the Late period ([S]OV/[S]VO). ${ }^{9}$

$\S 3$. With regard to Late and Vulgar Latin, however, there are only a few specialised papers dealing with potential historical changes in the position of the verbs which present special difficulties in the language, not only with their complex semantic content but also with their ability to form multiple constructions. ${ }^{10}$ This is the case with the verb sum in structures expressing a semantic notion of location. The relationship between word order and definiteness in these structures has been examined by scholars attempt-

1 Cf. S. A. Thompson (1978); D. BLAZER (1980); M. DuRANTE (1981: 62); G. INEICHEN (1987: 14); (1993: 86); A. ZAMBONI (1998: 104); B. L. M. BAUER (1995: 5 ff.).

2 Accompanied by the process of declension loss.

3 Cf. e.g. G. Calboli (1978) or A. Nocentin (1990: 156).

4 Cf. V. Väänänen (1987: 51), who refers to E. A. Bechtel (1907: 144); W. van OORde (1930: 96); E. LöfSTEDT (1911: 64); ThLL VII, $1355 \mathrm{ff}$. and VII, 2 ff.

5 Cf. A. ORLANDIN (1995: 125): "Non esiste articolo in latino volgare: ille ed ipse sono sempre degli 'articlöidi'." ORLANDINI, in her turn, adopts the views of M. SELIG $(1989,1992)$.

6 Cf. A. Nocentin (1990: 137).

7 Cf. J. H. GREenBerg (1963).

8 Cf. the bibliography quoted in C. Cabrulana (1999); cf. also C. Cabrillana-M. Díaz de Cerro (2000, § $7)$.

9 Thus e.g. J. N. Adams (1976: 99); D. G. J. Panhuns (1984); M. L. Porzio (1986); C. Cabrillana (1999).

${ }^{10}$ Cf. C. Cabrtllana (1998). 
ing to explain the difference between the so-called 'locative' constructions (Loc) and 'existential-locatives' $(E x L),{ }^{11}$ both containing the verb sum: while the former typically front the location-encoding term $(p)$ with a definite subject, the latter display the opposite distinctive features (a S[-Def $]^{12}$ appearing in the $\mathrm{pS}$ sequence).$^{13}$

\section{THE PURPOSE, CORPUS AND STRUCTURE OF THE PAPER}

$\S 4$. The present paper focuses on the two above-mentioned parameters, which are of interest because of the possible interrelation in their development. The issues outlined above can be studied particularly well on the locative and existential-locative structures.

$\S 5$. The research corpus consists of narrative and/or historical texts (Peregr. ${ }^{14}$ and Oros. hist. 1-5). The reasons are: (i) these are subject to fewer metrical and stylistic restrictions than other types of text, (ii) the content itself demands the inclusion of

11 Cf. E. V. Clark (1978: 91-101); T. Givón (1978: 306 ff.); S. Kuno (1971); C. Lyons (1999: 88-89); CABRILLANA (2001). In Classical Latin, where the predictions of word order are not fulfilled, these structures may be exemplified by the following: Loc: ubi nunc ficus Ruminalis est (Liv. 1.4.5); ExL: vastae tum in his locis solitudines erant (Liv. 1.4.6).

12 However, the principle of the subject being \pm Definite does not work unequivocally and universally. Since the analysis seems to confirm the definiteness restriction (cf. e.g. C. Lyons (1999: 236-246), who implies a certain correlation between the (in)definiteness of the subject and the typological distinction established between the locative and existential-locative construction; indeed, the existential constructions of languages which possess special markers for the ExL structure (there) are presented as grammatical contexts which confirm the indefiniteness of a term), the rare examples displaying the inverse correlation (Loc: TS [-Def] $\because:$ ExL: TS [+Def]) are of particular interest.

The presence of a [-Def] subject in locative constructions is a well-documented interlinguistic phenomenon; this fact is quite bizarre in terms of regularity, but in no way seems to threaten any restriction of grammaticality (cf. C. LYoNs, 1999: 237); thus: ultimum orationis fuit, se arma capere, vocare omnes Quirites ad arma; si qui impediat, iam ... se Publio Valerio consularis imperii, iam tribuniciae potestatis sacratarumque legum oblitum, quisquis ille sit, ubicumque sit, in Capitolio, in foro, pro hoste habiturum (Liv. 3.17.7). This example reveals the anomaly of a locative expression whose subject possesses a low degree of definiteness due to its non-specific, indefinite reference (qui impediat, ... quisquis ille sit), but the typological parallel clearly suggests a locative interpretation ('any who resists [sc. taking arms], whoever and wherever he may be, on the Capitol or in the Forum, ...') rather than existential-locative ("*there exist some people who resist wherever they are, on the Capitol or in the Forum, ...').

By contrast, the presence of a [ +Def] subject in an existential-locative structure threatens the definiteness restriction not only as an anomaly but as a 'non-grammaticality' in some languages (even in languages lacking definite articles: $c f$. the argument of HuANG (1987) ap. C. Lyons (1998: 240) on Mandarin). However, C. Lyons (1999: 239) points out that the definiteness restriction is far from being as categorical in English as it is usually assumed in linguistic discussions, and its expression is particularly complex in Latin (erat tum inter equites tribunus militum A. Cornelius Cossus... (Liv. 4.19.1) (?)). As the extensive research into existentials has underlined, the presence of a [+Def] subject in an existential-locative structure is made possible by exceptional communicative contexts ('listing-', 'reminders-', 'amount readings': cf. C. Lxons (1998: 241-246)) which assign, in terms of Functional Grammar, the pragmatic function of Focus to the subject. The problem raised is still an open question. Cf. M. DiAz DE CERIo (2002).

13 This is what could be called the 'Hypothesis of Definiteness'. On the behaviour of this Hypothesis in Classical Latin and Ancient Greek, cf. C. CABrILlanA-M. DíaZ DE Cerio (2000). Of the Vulgar Latin texts, the prediction tends to be fulfilled in Egeria ( $\mathrm{Loc}=\mathrm{Sp}: 61.53 \%:: \mathrm{ExL}=\mathrm{pS}: 61.12 \%$ ) but not in Orosius, where the most usual sequence is pS regardless of the kind of construction (Loc: $71.43 \%$; ExL: 63.64\%).

14 The analysis includes only the first 23 chapters - that is, the narrative part - as the most exhaustive source of locative constructions, since the part describing liturgical rites yields far fewer examples. As corroborated by R. LAPESA (1961: 26) or A. NOCENTINI (1990: 149), the liturgical part contains fewer demonstratives as well, for the writer does not proceed in the same way as when relating personal experiences. 
topographical digressions (excursus), ${ }^{15}$ which invite the use of otherwise less frequent ${ }^{16}$ locative structures, and (iii) the period of the selected texts falls within the larger frame ${ }^{17}$ proposed as the most significant in the evolution of the key parameters discussed in this paper. At another level, the texts - the Peregr. in particular - show an unavoidable, more or less conscious overlap of functions and tendencies typical of a transition period,,$^{18}$ as well as a mixture of grammatical levels or systems. ${ }^{19}$ As a foil for evolutionary comparison, I have selected a text from the Classical period (Liv. 1-4).

$\S 6$. The paper starts with a brief explanation of the theoretical concepts used in this research (2) and considered suitable to carry out the analysis (3). A general presentation of the data gleaned from both texts (3.1) is followed by an examination of the different methods indicating the definiteness of a term in Latin (3.2), with a special focus on demonstratives (3.2.2). The final section (3.3) tackles the order of the basic constituents in locative constructions, in order to establish the relationship between the two analysed parameters.

\section{PRELIMINARY CONCEPTS}

$\S 7$. The inclusion of the definiteness (Def) analysis calls for a clarification of the concepts assigned to that parameter, a task which presents difficulties both in its own right and in the context of the proposed research. The aim of this paper, however, is not to provide a theoretical approach to the above-mentioned parameter, but rather to examine its influence and behaviour in the texts. The discussion will therefore limit itself to clarifying the sense in which some of the concepts are used.

$\S 8$. Definiteness is necessarily related to variables belonging to different linguistic levels: (i) to the semantic level, through the property of referentiality; (ii) to the grammatical level, through the formal reflection of determination. Differing from language to language, the system of determination is apparently responsible for the listener's identification of an entity as \pm Definite.

The referential terms that will be considered are those able to process \pm Def, that is to say, those relating linguistic expressions ${ }^{20}$ to real or possible entities (referents). ${ }^{21}$ Among them, we will assume that indefinite terms ([-Def]) refer to entities which are

${ }^{15}$ On Orosius' work, cf. especially S. SALOR (1982: 29, 56). Orosius is familiar with the Classical historiographical sources and displays a certain ambition to imitate the canonical works, e.g. through brevitas and ordo, although a mixture of not wholly classical genres can be observed as well.

${ }^{16}$ Cf. Ch. H. KaHN (1973: 157).

${ }^{17}$ Cf. A. ZAMBon (1998: 123): between the fourth and the sixth centuries.

${ }^{18}$ Cf. V. VÄ̈̈NÄNEN (1990: 160, passim); A. NOCENTINI (1990: 137).

19 As has been lucidly expressed by A. NoCENTIN (1990: 148): "Egeria non aveva uNA grammatica, ma almeno due: quella della propria lingua materna e quella del latino apresso a scuola." This could be complemented by an observation of V. VÄANARNEN (1990: 165): "Il linguaggio orale presente nell'Itinerarium Egeriae si può dividere in due livelli o piani, (...): uno, che racchiude la porzione più spontanea, intrinseca all'uso particolare dell'autrice; e l'altro, caratterizzato da modi popolari o familiari che vengono adoperati intenzionalmente, allo scopo di rendere delle parole dette a viva voce, non testualmente, ma bensì rispettandone il senso e il tono."

${ }^{20}$ Cf. T. Grvón (1978: 296); J. Lyons (1980: 173-188); S. C. Dik (1989: 143-146).

${ }^{21}$ Cf. W. L. CHAFE (1976: 28): "A referent is the idea a noun is used to express" (where "idea" refers to "particular individuals and events"). 
not identifiable by the listener, in contrast to definite terms ([+Def $])$, which refer to identifiable entities and enable a 'referent identification'.

Conversely, the identifiability of a referent by the listener has been approached from the pragmatic point of view. According to this, various 'sources of availability'22 can be established from which the listener obtains information:

(i) long-term pragmatic information/general knowledge ('the sun', 'Paris');

(ii) current pragmatic information introduced in the preceding discourse (' $I$ have bought a car; you will see it tomorrow');

(iii) information which is perceptually available in the situation ('do you see the man with the green sweater?'); and

(iv) inference from the information available in any of the sources (i)-(iii) presented above ('a submarine ... the hatch').

$\S 9$. Among the grammatical reflections of definiteness, the presence/absence of the article is the most prominent, but not the only one. Other marks of definiteness are formed by lexical and word-class distinctions. Of these, lexical differentiation ${ }^{23}$ exceeds the boundaries of the present study, but as for word-classes, it is proper nouns, demonstratives, ${ }^{24}$ etc. that are particularly operative.

$\S 10$. The relationship between the pragmatic and grammatical levels originates from causality: what causes a term to display some of the above-mentioned distinctions, making it \pm Definite, is the availability of its referent to the listener, from one or more of the four basic sources. For example, what makes a proper noun or noun with only one referent assign \pm Definiteness to a term is general knowledge. On the other hand, the ability to identify a referent from the previous context is demonstrated by the use of personal pronouns, demonstratives, relatives, and the like.

In order to carry out the proposed survey, we must therefore examine what impact the \pm Definiteness of the terms involved has on the discourse. In this, then, we count on external data to establish the degree of development attained by the grammatical markers of definiteness in such texts.

$\S 11$. This paper excludes the analysis of: (i) constructions containing auxiliary verb forms with a nominal function; (ii) those presenting syntactical structures open to ambiguous interpretation (attributive/locative, existential/possessive, and such); (iii) lexicalised expressions; and (iv) metaphorical uses of the locative construction.

${ }^{22}$ Cf. S. C. DIK (1989: 114).

${ }^{23}$ As in Classical Latin, lexical differentiation is practically non-existent in the analysed texts, except for the use of habet with an object as complement: Achaia undique propemodum cincta est mari; nam ab oriente habet Myrtoum mare, ab euro mare Creticum, ..., ab aquilone angustum terrae dorsum, quo Macedoniae coniungitur vel potius Atticae; qui locus Istmos vocatur, ubi est Corintus, habens in Atticam ad boream non longe Athenas civitatem (Oros. hist. 1.2.58); nam cum ipse mons ... nec fruticem habeat (Peregr. 3.6).

${ }^{24}$ Generally, but on a smaller scale and in specific contexts, personal pronouns, possessive pronouns and quantifiers can be included as well: cf. infra, 3.2. 


\section{ANALYSIS}

\subsection{Preliminary data}

$\S 12$. The sum total of the locative constructions is distributed between the two texts as follows:

Table 1: Total Number of Examples

\begin{tabular}{|llll|}
\hline Corpus & Loc & ExL & Total \\
Peregr. & 51 & 27 & 78 \\
Orosius & 22 & 16 & 38 \\
\hline
\end{tabular}

$\S 13$. Even a cursory glance reveals that the total number of examples is significantly higher in Peregr. than in hist. ${ }^{25}$ This ratio can be explained by the following factors:

(i) The type of passage examined, which is more descriptive throughout Egeria's text than in the five books of Orosius, except for hist. 1-2.

(ii) The overuse of the passive voice, with verbs that define more fully the simple value of location expressed by the esse forms. ${ }^{26}$

(iii) The consequent increasing use of the verb esse as an auxiliary form in the passive, ${ }^{27}$ resulting in a gradual loss of its wide semantic range and restriction to copulative-identifier structures.

(iv) The author's characteristic conciseness, fairly often leading to the suppression of the verb: not only in copulative-identifier constructions, which are transformed into the so-called 'pure nominal' ${ }^{28}$ structures, but also in constructions where the verb form would normally operate with a location value..$^{29}$

(v) The use of alternative structures, typical of this language period, to convey notions including location.

\subsection{Markers of \pm Def}

\subsubsection{General analysis}

$\S 14$. According to our statements in 1 , it is the subject of Loc constructions which would generally claim the feature + Def. This feature presents the following 'encoding' possibilities, depending on the source of availability:

I. Long-Term Pragmatic Information Ia. Proper Noun

\footnotetext{
${ }^{25}$ Nevertheless, owing to the low frequency of these constructions and to considerations of manoeuvrability, we operate with an insufficient amount of data to establish any far-reaching conclusions; an extension of the corpus may well qualify the results yielded here.

${ }^{26}$ Cf. e.g.: Asia tribus partibus oceano circumcincta per totam transversi plagam orientis extenditur (Oros. hist. 1.2.2); (mons Caucasus inter Colchos, ..., et inter Albanos, ..., primum attollitur (Oros. hist. 1.2.36); insula Creta finitur $a b$ Oriente Carpathio mari, ab occasu et septentrione mari Cretico, a meridie mari Lybico (Oros. hist. 1.2.97).

${ }^{27}$ Quae (sc. insulae) in aversa Galliarum parte ad prospectum Hispaniae sitae sunt (Oros. hist. 1.2.76).

${ }^{28}$ In tanta malorum multitudine difficillima dictis fides (Oros. hist. 3.16.8).

${ }^{29}$ A fonte Tigridis usque ad Carras civitatem inter Masagetas et Parthos mons Ariobarzanes (Oros. hist. $1.2 .41)$; the same pattern is found in $1.2 .42 ; 1.2 .43 ; 1.2 .44 ; 1.2 .45$, etc.
} 
Ib. Proper Noun in the Genitive

Ic. $\varnothing$

II. (Preceding) Discourse

IIa. 'Demonstrative'30

IIb. Relative Adjective

IIc. Relative Pronoun31

IId. Apposition

IIe. ø

[IIf. Personal Pronoun

IIg. Possessive Pronoun

IIh. Quantifier]32

III. Inference

$\S 15$. The subject term analysis of the corpus selected for this research, compared to a text from the Classical period, reveals the following distribution:

Table 2: Strategies for Encoding Definiteness of the $S$

\begin{tabular}{|c|c|c|c|c|}
\hline Strategies for Definiteness & Liv & & Orosius & Peregrinatio \\
\hline \multicolumn{5}{|l|}{ I. GENERAL KNOWLEDGE } \\
\hline Ia. Proper Noun & 14 & $(25.45 \%)$ & $(72.72 \%)$ & $(23.52 \%)$ \\
\hline Ib. Proper Noun in the Genitive & 5 & $(09.09 \%)$ & $(18.18 \%)$ & $(15.68 \%)$ \\
\hline Ic. $\varnothing$ & 0 & $(00.00 \%)$ & 0 & $(01.96 \%)$ \\
\hline \multicolumn{5}{|l|}{ II. (PRECEDING) DISCOURSE } \\
\hline ПIa. Demonstrative & 1 & $(01.81 \%)$ & 0 & $15 \quad(29.41 \%)$ \\
\hline IIb. Relative Adjective & 0 & & 0 & $1 \quad(01.96 \%)$ \\
\hline Ic. Relative Pronoun & & $(20,00 \%)$ & $(09.10 \%)$ & $(09.80 \%)$ \\
\hline IId. Apposition & 1 & $(01.81 \%)$ & 0 & $(01.96 \%)$ \\
\hline Ile. & 17 & $(30.96 \%)$ & 0 & $(13.75 \%)$ \\
\hline IIf. Personal Pronoun & 2 & $(03.63 \%)$ & 0 & 0 \\
\hline IIg. Possessive Pronoun & 1 & $(01.81 \%)$ & 0 & 0 \\
\hline Ilh. Quantifier & 2 & $(03.63 \%)$ & 0 & 0 \\
\hline III. INFERENCE & 1 & $(01.81 \%)$ & 0 & $(01.96 \%)$ \\
\hline TOTAL & 55 & & 22 & 51 \\
\hline
\end{tabular}

30 This term will be generically applied to all terms which can fulfill an anaphoric function in the Classical period.

${ }^{31}$ In these cases, the antecedent of the relative pronoun (if there is one) is considered, and the pronoun is identified as a marker of definiteness only when its convergence with the antecedent provides a distinct Def. The nominal relative clause is itself generically assigned to this section, e.g. Tarquinium moribundum cum qui circa erant excepissent (Liv. 1.41.1). Cf. the analysis infra ( $\$ 15)$.

32 The last three markers have only been analysed in the text from the Classical period. C. Lyons (1999: 24) has revised the traditional opinion which includes the possessive among Def markers; this property is doubtful also for quantifiers which appear in ExL constructions, and consequently with indefinite subjects: forte in duobus tum exercitibus erant trigemini fratres (Liv. 1.24.1). 
The above data yield the following hierarchy of definiteness-encoding procedures for the three corpora:

Table 3: A Quantitative Hierarchy of Strategies for Encoding the Definiteness of the $\mathbf{S}$

\begin{tabular}{|l|l|l|}
\hline Livy & Orosius & Peregrinatio \\
\hline & & \\
\hline (Preceding) Discourse (ø) & Proper Noun & Demonstrative \\
\hline Proper Noun & Proper Noun in the Genitive & Proper Noun \\
\hline Relative Pronoun & Relative Pronoun & (Preceding) Discourse (ø) \\
\hline Proper Noun in the Genitive & & Relative Pronoun \\
\hline Pers. Pronoun /Quantifier & & $\begin{array}{l}\text { Gral. Know./App./Rel. Adj./ } \\
\text { Infer. }\end{array}$ \\
\hline Dem./App./Posses. Pro./Infer. & & \\
\hline
\end{tabular}

$\S 16$. Although some examples display more than one source of availability, ${ }^{33}$ the Peregrinatio is clearly dominated by demonstratives, in contrast to Livy and Orosius. Since this discrepancy can be partly explained with Orosius' tendency to imitate classicism, it seems suitable to analyse each non-classical text separately.

The data shown above indicate the frequency of the procedures which, to a larger or lesser extent, establish a degree of definiteness in the subject term. Before any further discussion, however, it is necessary to clarify some points, particularly with regard to the procedures most frequently employed:

1. Contrary to Late Latin texts, Classical prose is characterised by the absence of grammatical definiteness markers. This implies an expectation that, despite the lack of lexical or grammatical markers, the reader/listener will be able to identify an entity as definite because of the preceding context.

2. On the other hand, the use of proper nouns - either as nuclei or as determinatives in the genitive - is revealed as one of the most efficacious and unmistakable markers of definiteness. This procedure does not exclude others but can in fact combine with them; thus, for instance, this marker is in many cases coupled with that of general knowledge (1) or of the preceding context (2):

(1) (iunctus est cum eo loco) quo sunt Memoriae concupiscentiae (Peregr. 1.1): "(next to the spot where the mountains open out is the place of the "Graves of Craving""

(2) (in eo loco) ubi fuit domus sancti Abrahae (Peregr. 20.3): "first he took us to a church outside the city;" (...) (ecclesia) ubit fuit primitus domus Abrahae (Peregr. 20.5):

3. The use of the relative pronoun as $\mathrm{S}$ opens two possibilities: (i) the definite quality of the antecedent (if present) spreads to the relative pronoun (3); (ii) the definiteness of

\footnotetext{
${ }^{33}$ E.g. the preceding discourse as well as a proper noun in the genitive (Peregr. 20.5); a demonstrative pronoun as well as apposition (Peregr. 20.11), etc.
} 
the $S$ is the result of the antecedent being implicit in the relative pronoun of a nominal relative clause. In the latter case, it should be pointed out that, while relatives with no antecedent can appear in Livy - (4) -, the texts by Egeria and Orosius always contain an antecedent with a degree of definiteness which is completed with the relative clause [(5)-(5')]. In the ranking shown in Table 3, this procedure is listed in the third place, but its frequency varies: it amounts to $20 \%$ in Livy, while Orosius and the Peregr. display the similar figures of $9.10 \%$ and $9.80 \%$ respectively.

(3) (a meridie mari Africo) quod est contra Subventanos et Syrtes minores (Oros. hist. 1.2.100)

(4) sunt qui eam ex pacto tradendi quod in sinistris manibus esset derecto arma petisse dicant (Liv. 1.11.9)

(5) (spelunca, ubi latuit sanctus Helias, in hodie ibi ostenditur ante hostium ecclesiae) quae ibi est (Peregr. 4.2)

(5') (nunc insularum), quae in Nostro mari sunt (Oros. hist. 1.2.95)

4. The inference source, though scarce in the analysed texts, reveals itself as an efficacious means of indicating \pm Def:

(6) ductus exercitus ad Carventanam arcem, quamquam invisus infestusque consuli erat, impigre primo statim adventu deiectis qui in praesidio erant arcem recipit (Liv. 4.53.9)

(7) intra quam ecclesiam, in eo loco ubi pulpitus est (Peregr. 12.1)

5. Because of their importance for the proposed analysis, we shall now examine the word-classes generically included among demonstratives.

\subsubsection{Demonstratives}

$\S 17$. The frequent use of demonstratives as Def markers in Egeria's text is by itself an indication of the gradual loss of their deictic function. This development may be clearly perceived in the cases of ille and ipse. According to Nocentini, the two demonstratives tend to become associated with known information, which may or may not have appeared in the preceding discourse. Thus they develop into increasingly emphatic signals for the listener to identify the entity involved, as seen in the following example:

(8) requisivi ubi esset puteus ille ubi sanctus Iacob potasset pecora, quae... Et ait mihi episcopus 'in sexto miliario est hinc locus ipse iuxta vicum, qui fuit ...' (Peregr. 20.11)

In the case of (8) - an answer in direct speech -, the information expressing the subject is underlined by the use of ipse with locus and thus rendered as a definite entity, as is appropriate for the subject of a Loc construction. This example confirms the scheme proposed by Nocentini (1990: 146), who marks the features of ipse as [+detto +testo] in contrast to the [-detto +testo] of ille. However, there are also examples which seem to contradict this analysis:

(9) requisivi a sancto episcopo, ubinam esset locus ille Chaldeorum, ubi... Tunc ait mihi ipse sanctus episcopus: 'locus ille, ..., est hinc intus in Persida...' (Peregr. 20.12) 
This 'contradiction' actually reflects a fluctuating use, which can be enhanced by the co-existence of more than one 'system' in the Peregr., as stated above. ${ }^{34}$

$\S 18$. The use of demonstratives assigns the property \pm Def also to terms expressing location, especially where the + Def of such terms contrasts with the indefinite quality characteristic of the subject in ExL constructions. In (10), the first occurrence of a yet unknown entity - 'a hill' - in the text contains no (in)definiteness markers, whereas its second appearance, as of information already known, carries the determinative ipse. In the latter structure, the new information is conveyed by the subject, which is accompanied by a marker of genericity (plurima):

(10) et quoniam inde ad sanctam Teclam, qui locus est ultra in colle sed plano, habebat.... (...). Sed ut redeam ad rem, monasteria ergo plurima sunt ibi per ipsum collem (Peregr. 23.2-4)..$^{35}$

Examples of these and other demonstratives displaying the contrast between unknown and known information are (11)-(14):

(11) accessimus... ad eum locum, ubi steterat sanctus Aaron cum septuaginta senioribus, .... In eo ergo loco ${ }^{36}$ licet tectum non sit, ..., tamen petra ingens est per girum (Peregr. 4.4)

(12) in eo loco, ubi monasteria sunt plurima et ecclesia in capite vallis ipsius. Ante ipsam autem ecclesiam hortus est gratissimus (Peregr. 4.7)

(13) vidi super ripam Iordanis fluminis vallem pulchram... . Nam in ea valle vicus erat grandis (Peregr. 13.3)

(14) in medio loco est monticulus non satis grandis... . Nam in isto colliculo, (qui...). ecclesia est, quae ... (Peregr. 13.3-4)

It seems clear, then, that there is a tendency - especially in the Peregr. - to associate a known and definite entity with the presence of certain demonstratives whose deictic function is weakening and shifting towards a 'phoric' one, thus forming a prelude to the Romance article. ${ }^{37}$ The indefinite and unknown entities, by contrast, usually display an absence of markers. ${ }^{38}$ Sometimes, however, they are marked by an element that seems to have lost its quantifying value to acquire another, which will in time become characteristic of the indefinite article:

${ }^{34}$ Cf. $\$ 5$.

${ }^{35}$ Although the strategy is generalised particularly by Egeria, it is not exclusive to her: mons Caucasus inter Colchos, ..., et inter Albanos, ..., primum attollitur. (...). Itaque ipse Caucasus inter Colchos et Albanos, ... (Oros. hist. 1.2.36-39). The contrast between the initial absence of markers and the subsequent addition of ipse can also be observed in locative structures with verbs other than sum: haec est auten vallis, in qua factus est vitulus, qui locus usque in hodie ostenditur: nam lapis grandis ibi fixus stat in ipso loco (Peregr. 2.2).

${ }^{36}$ The preceding context reads: accessimus... ad eum locum, ubi steterat sanctus Aaron cum septuaginta senioribus. On the particulars of the prepositional phrase in eo loco, sometimes followed by a specification (in eo loco ubi fuit domus sancti Abrahae, Peregr. 20.3), and its possible adverbial nature, cf. E. LÖFSTEDT (1911: 143); R. AMBROSINI (1955: 101); V. VÄÄNÄNEN (1987: 25-26). On the occurrence of the $[\mathrm{N}+$ demonstrative+relative] pattern in the role of an article, cf. H. Rosén (1994: 131).

${ }^{37}$ From this perspective, H. RosEN (1994: 145) states: "The date of the emergence of the definite article in Latin may be pushed backward, much earlier than the communis opinio has it, to the fourth century."

${ }^{38}$ Cf. § 8 . 

$8.2)^{39}$

(15) nunc autem ibi nichil aliud est nisi tantum unus lapis ingens Thebeus (Peregr.

\subsection{Constituent order}

$\S 19$. A discussion of this parameter must consider also the constructions where one of the constituents has a fixed position: cases where the subject (S) or a locative expression (p) is encoded by a relative pronoun or adverb. Given the generally accepted evolution SOV > SVO, the subject of transitive constructions would not be expected to alter its position. On the other hand, the present study examines intransitive constructions as well. Thus the analysis basically focuses on the position of the verb, absolute and relative (that is, relative to the $S$ and $p$ ). This approach allows us to ascertain whether intransitive verbs, particularly exceptional ones like sum, undergo a similar historical change of position as transitive ones.

$\S 20$. After excluding the constructions whose subjects are bound to the initial position, we obtain the following data on the absolute and relative positions of the verb:

Table 4: Sequence of Constituents: Absolute Position of the Verb

\begin{tabular}{|l|l|l|l|l|l|l|}
\hline \multicolumn{3}{|c|}{ Loc } & \multicolumn{3}{c|}{ ExL } \\
\hline Position & Livy & Peregr. & Orosius & Livy & Peregr. & Orosius \\
\hline Initial V & $03.22 \%$ & $01.96 \%$ & $00.00 \%$ & $04.56 \%$ & $07.38 \%$ & $06.25 \%$ \\
\hline Media V & $03.22 \%$ & $60.78 \%$ & $34.79 \%$ & $22.72 \%$ & $55.55 \%$ & $18.75 \%$ \\
\hline Final V & $93.56 \%$ & $37.26 \%$ & $65.21 \%$ & $72.72 \%$ & $37.03 \%$ & $75.00 \%$ \\
\hline
\end{tabular}

Table 5: Sequence of Constituents: Relative Position SV/VS

\begin{tabular}{|l|l|l|l|l|l|l|}
\hline \multicolumn{4}{|c|}{ Loc } & \multicolumn{3}{c|}{ ExL } \\
\hline Sequence & Livy & Peregr. & Orosius & Livy & Peregr. & Orosius \\
\hline SV & $96.77 \%$ & $63.63 \%$ & $78.57 \%$ & $63.63 \%$ & $50.00 \%$ & $75.00 \%$ \\
\hline VS & $03.23 \%$ & $36.37 \%$ & $21.43 \%$ & $36.37 \%$ & $50.00 \%$ & $25.00 \%$ \\
\hline
\end{tabular}

Table 6: Absolute and Relative Positions of the Verb: Total Percentage

\begin{tabular}{|l|l|l|l|}
\hline Position & Livy & Peregr. & Orosius \\
\hline Initial V & $03.78 \%$ & $03.86 \%$ & $02.57 \%$ \\
\hline Medial V & $11.32 \%$ & $58.97 \%$ & $28.20 \%$ \\
\hline Final V & $84.90 \%$ & $37.17 \%$ & $69.23 \%$ \\
\hline Sequence & Livy & Peregr. & Orosius \\
\hline SV & $83.01 \%$ & $42.38 \%$ & $76.66 \%$ \\
\hline VS & $16.99 \%$ & $57.62 \%$ & $34.24 \%$ \\
\hline
\end{tabular}

\footnotetext{
$\overline{39}$ For a similar use cf. V. VÄÄNÄNEN (1987:57): dicitur ibi oratio apta loco et diei, dicitur etiam unus ymnus aptus (Peregr. 36.1).
} 
The statistical analysis given in Table 6 may be represented by the following charts:

\section{Graphic 1}

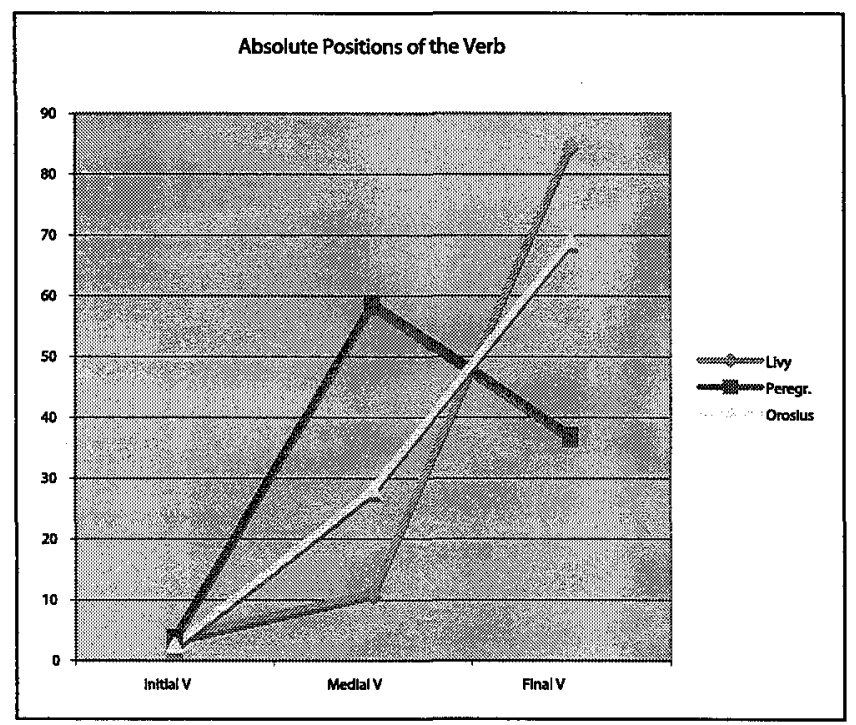

\section{Graphic 2}

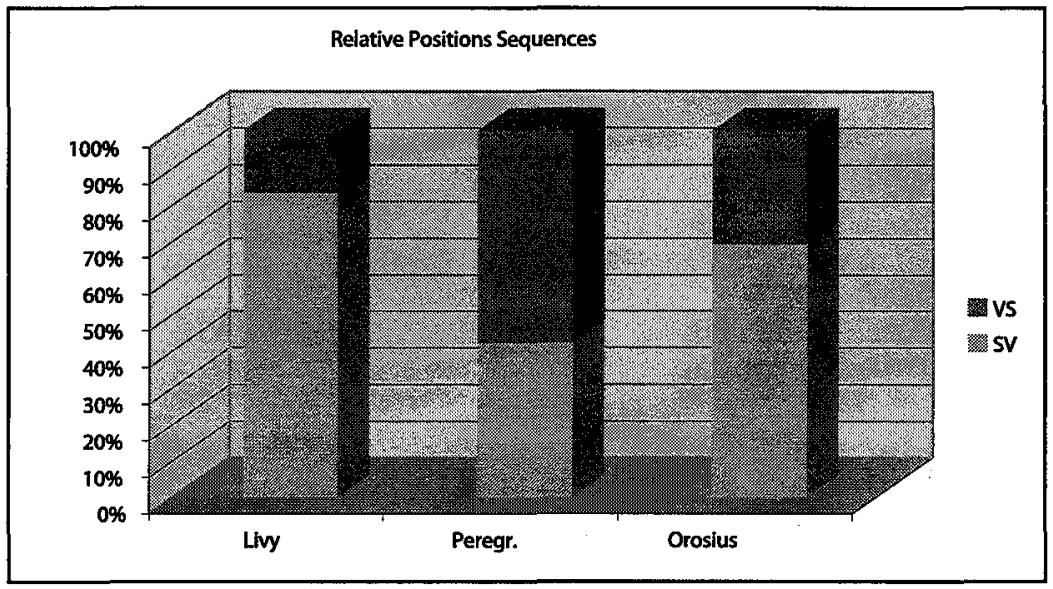

$\S 21$. The data shown in the tables above provide the basis for several conclusions: 1 . The tendencies observed are clearer in Loc constructions than in ExL structures.

2. There is a shift of the verb towards the medial position, which is much more pronounced in Egeria than in Orosius. The discrepancy is probably due to the latter having 
been more strongly influenced by the literary conventions of the Classical period, which established a fixed position for certain constituents.

3. Similarly, there is a growing tendency towards replacing the sequence $\mathrm{SV}$ with the inverse VS..$^{40}$ It seems to be more common with sum than with other verb types. ${ }^{41}$

$\S 22$. In connection with the last point, I believe that we must focus on the smaller proportional difference between the two sequences in the Peregr., which displays a seemingly unmotivated alternation of the patterns SpV/SVp and pSV/pVS. An examination of the individual examples of these sequences in Loc and ExL constructions reveals that the relative position of their constituents is, in fact, 'to a certain extent' indifferent, because the 'speaker' enables the 'listener' to identify the located entity (the subject) in Loc constructions as definite by (i) the assignment of a definite demonstrative, or (ii) the use of word-classes with a high degree of definiteness per se, such as proper nouns. The subject of ExL constructions, by contrast, lacks all markers of definiteness:

I. SpV Loc:

(15a) specialis autem ille (sc. mons), ... in medio illorum omnium est (Peregr. $2.5)^{42}$

SpV ExL:

(15b) aecclesia ibi est (Peregr. 3.1) $)^{43}$

II. SVp Loc

(16a) Moyses... fuit ibi (Peregr. 2.2) $)^{44}$

SVp ExL

(16b) (monasteria) quaecumque erant ibi (Peregr. 4.5) ${ }^{45}$

III. pSV Loc

(17a) in quo horto ipse rubus est (Peregr: 4.7)

pSV ExL

(17b) ibi ergo in summo ecclesia est (Peregr. 12.3)

IV. pVS Loc

(18a) et ibi est memoria sancti Gethae (Peregr. 16.1)

pVS ExL

(18b) ubi est rubus (Peregr. 2.3)

40 The abundance of VS sequences is noted already by V. VÄANÄNEN (1987), although he does not provide precise statistics. It is due, among other reasons, to the passive or intransitive character of the verb - the segment which introduces the clause and/or the new information conveyed by the message.

${ }^{41} \mathrm{G}$. Hinojo (1986) arrives at the following ratio: $\mathrm{SV}=62.4 \%:: \mathrm{VS}=37.6 \%$.

${ }^{42} \mathrm{Cf}$. also: toti illi montes... infra nos essent (Peregr. 2.6); ipse locus in campo grandi est (Peregr. 21.4).

43 The same pattern is displayed in: via enim illic penitus non est (Peregr. 6.1); nam et memoriale ibi est (Peregr. 12,6) or multi monachi ibi sunt (Peregr. 20.11).

44 Also: (his diebus, quibus) Moyses fuit in montem (Peregr. 5.3); qui locus est ultra civitatem in colle sed plano (Peregr. 23.2). I consider the relative element to have a local adjective function; it is not a case of attraction.

${ }^{45}$ Other similar examples: nam castrum est ibi nunc (habens...) (Peregr. 7.4); et sancta ecclesia est ibi (Peregr. 20.11). 
$\S 23$. It may be concluded that the presence of definiteness markers allows a certain freedom in the order of constituents. Sometimes, however, the listener's extra-textual knowledge of an entity, as well as its previous occurrence in the text, enables it to be identified as definite on its subsequent occurrences. In such cases the presence of a grammatical marker is not necessary, and the order of the terms whose position is not fixed (S and $\mathrm{V}$ ) may vary:

(19a) Moyses... locutus est ei Deus de rubo in igne (Peregr. 2.2)

(19b) denuo ad illud caput vallis descenderemus, id est ubi rubus erat (Peregr. 2.3)

(19c) descendentes a monte Dei, ubi est rubus (Peregr. 2.3)

(20a) ubi fuit primitus domus Abrahae (Peregr. 20.5)

(20b) ubi primitus domus sancti Abrahae fuit (Peregr. 20.8)

(21a) ubi monasteria sunt plurima (Peregr. 4.7)

(21b) ibi erant monasteria plurima sanctorum hominum (Peregr. 4.6)

$\S 24$. To sum up: in Late Latin, and especially in the text of Peregr., the marking of terms for definiteness is at an intermediate stage, oscillating between the absence of such markers and the setting-up of a system which would comprise not only lexical but also grammatical ones.

\section{CONCLUSIONS}

$\S 25$. From a global perspective, the data in this corpus allow us to perceive an evolution in the order of constituents employed in the examined structures - one that is more evident in Egeria than in Orosius. There are tendencies to place the verb in the medial position, to make increasing use of the VS sequence at the expense of the Classical SV, and to include the verb sum proportionally more often than other types of verb.

$\$ 26$. Among the different procedures for encoding definiteness which are not mutually exclusive, the use of demonstratives, scarcely present in Livy, gains ground and reaches the highest frequency with Egeria. As evidenced by examples (cf. § 2.2.2), demonstratives - especially ille and ipse - gradually lose their prominent deictic function, a process which is still unfinished in the period examined here. This mutation is associated with factors of a pragmatic-contextual nature, which assume a key role in the use of definiteness markers, and thus in the distinctions between the analysed structures in Late Latin.

$\S 27$. Undoubtedly, the tendency to associate definiteness with the presence of lexical markers developed in Late and Vulgar Latin and vice versa seems justified. It is, however, possible to reason as follows:

1. The word order of Classical Latin is generically defined as free but not indifférent. ${ }^{46}$ At this stage of the language, with no complete lexical or grammatical system to mark definiteness, it runs counter to what is predicted by the Hypothesis of Definiteness: ${ }^{47}$

${ }^{46}$ Cf. J. Marouzeau (1938: 55).

${ }^{47}$ Cf. $\S 3$. 
it does not play a truly distinctive role in Loc constructions, at least not in a clear and universal way. Nevertheless, the 'listener' is able to identify the \pm Definite entities.

2. During the transition from Late Latin to Romance languages, this word order gradually became fixed due to the progressive loss of declensions; moreover, a lexical and grammatical system evolved to mark the \pm Definiteness of terms. This system, however, could not replace word order in a role which the latter did not play.

3. Therefore it seems that the fixation of word order and the emergence and development of the article are not necessarily linked phenomena, ${ }^{48}$ although they can sometimes be interdependent, ${ }^{49}$ as has been commonly assumed.

\section{References:}

J. N. ADAMs, "A Typological Approach to Latin Word Order«, IF 81, pp. 70-99.

R. AMBrosIN, »Il tipo sintagmatico 'in eo loco《 e questioni di principio nello studio della 'Peregrinatio Aetheria' «, $A S N P$ s. II, 24, 1955, pp. 97-109.

B. L. M. BAUER, The Emergence of the Development of SVO Patterning in Latin and French, Oxford, 1995.

E. A. Bechtel, S. Siluiae Peregrinatio. The text and a study of the Latinity, Chicago, 1907

D. BLAZER, »Old French articles and word order change«, FLing 1,2, 1980, pp. 295-304.

C. CABRILlANA, "Structures of Identification and Attribution with sum«, in B. García-Hernández (ed.), Estudios de lingüística latina, I, Madrid, 1998, pp. 217-33.

C. Cabrillana, »Type of Text, Pragmatic Function and Constituent Order: a Comparative Study between the Mulomedicina Chironis and the Peregrinatio Egeriae«, in H. Petersmann-R. Kettemann (eds.), Latin vulgaire-latin tardif $V$, Heidelberg, 1999, pp. 319-30.

C. CABRILIANA, »Locative Structures in Constructions with sum«, in C. Moussy (ed.), De lingua Latina novae quaestiones, Leuven, pp. 275-90.

C. CABRILLANA - M. DIAZ DE Cerio, »Orden de constituyentes y Definición en las construcciones locativas con sum y 'einai': reconsideración de la Hipótesis de la Definición«, Linguistica 40,1, 2000, pp. 57-73.

G. CALBOLI, »Die Entwicklung der klassischen Sprachen und die Beziehung zwischen Satzbau, Wortstellung und Artikel«, IF 83, 1978, pp. 197-261.

G. CALBOLI, »Relatif de liaison et absence d'article en latin«, in C. Touratier (ed.), Syntaxe et Latin, Aix-en Provence, 1985 , pp. 361-79.

W. L. Chafe, »Givenness, Contrastiveness, Definiteness, Subjects, Topics and Point of View«, in Ch. N. Li (ed.), Subject and Topic, New York, 1976, pp. 25-55.

E. V. CLARK, "Locationals: Existentials, Locative and Possessive Constructions«, in J. H. Greenberg (ed.), Universals of Human Language, IV. Syntcx, Stanford, 1978, pp. 87-126.

M. DíAZ DE CERIO, „Una contribución al análisis de las construcciones existenciales-locativas y copulativolocativas en griego antiguo«, in M. Domínguez et al. (eds.), Homenaje a M. C. Diaz y Diaz, Santiago de Compostela, 2002, pp. 15-23.

S. C. Dik, The Theory of Functional Grammar: Part I: The structure of the clause, Dordrecht, 1989.

M. DuRANTE, Dal latino all 'italiano moderno. Saggio di storia linguistica e culturale, Bologna, 1981.

T. Gıvón, »Definiteness and Referentiality«, in J. H. Greenberg (ed.), Universals of Human Language, IV. Syntcx, Stanford, 1978, pp. 291-330.

J. H. Greenderg, "Some Universals of Grammar with Particular Reference to the Order of the Meaningful Elements«, Universals of Language, 1963, pp. 73-113.

G. Hinoso, »El orden de palabras en la Peregrinatio Aetheriae«, StudZam 7, 1986, pp. 81-87.

G. INEICHEN, «Zwischen Latein und Frühem Romanisch (Die Schwelle um 800 n. Chr.)«, in A. Arens (ed) Text-Etymologie. Festschrift fïr H. Lausberg zum 75. Geburtstag, Wiesbaden-Stuttgart, pp. 14-18.

\footnotetext{
48 In this respect, cf. S. A. THOMPSON (1976), who explains: "In a topic-prominent language (TVX), word order can be used to mark definiteness. When word order becomes more fixed, this means of definiteness marking is lost. Articles develop as a means of maintaining the definite-indefinite distinction." Her proposal assumes that the article comes into use when a TVX language changes into SOV or SVO, in opposition to T. VENNEMANN (1975), who focused on the shift from SOV to TVX.

49 Cf. H. Rosén (1994: 142).
} 
G. INEICHEN, $)$ L'apparition du roman dans des contextes latins«, in M. Selig-Frank-Hartmann (eds.) Le passage à l'écrit des langues romanes, Tübingen, 1993, pp. 83-90.

CH. H. KaHN, The verb 'be' in Ancient Greek, vol. 6 of 'The verb 'be' and its synonyms: philosophical and grammatical studies', M. Verhaar (ed.), = Foundations of Language, Suppl. Ser. 16. Reidel. Dordrecht, 1973.

S. KuNo, »The Position of Locatives in Existential Sentences«, LIn 2,3, 1971, pp. 333-78.

R. LAPESA, »Del demostrativo al artículo«, Nueva Revista de Filología Hispánica 15, 1961, pp. 23-44.

E. LÖFSTEDT, Philologischer Kommentar zur Peregrinatio Aetheriae, Uppsala, 1911.

C. LYons, Definiteness, Cambridge, 1999.

J. Lyons, Semántica, Barcelona, 1980.

J. MAROUZEAU, L'ordre des mots dans la phrase latine, 3 vol. (Les articulations de l'enoncé, Paris, 1949. Les groupes nominawx, Paris, 1922. Les verbe, Paris, 1938).

A. NoCENTINI, »L'uso dei dimostrativi nella Peregrinatio Egeriae e la genesi dell' articolo romanzo«, in Atti del Convegno internazionale sulla Peregrinatio Egeriae, Arezzo, 1990, pp. 137-58.

W. van OORDE, Lexicon Aetherianum, Amsterdam, 1930.

A. ORLANDIN, Il riferimento del nome. Un'analisi semantico-pragmatica del nome latino, Bologna, 1995.

D. G. J. PANHUIS, »Is Latin a SOV Language? A Diachronic Perspective«, IF 89, 1984, pp. 140-59.

M. L. Porzao, »Latin Declension: A Theoretical and Methodological Approach«, in G. Calboli (ed.), Papers on Grammar II, Bologna, 1986, pp. 1-18.

A. Rosév, »The definite article in the making, nominal constituent order, and related phenomena«, in J. Herman (ed.), Linguistic Studies on Latin, Amsterdam, 1994, pp. 129-50.

E. S. SALOR, »Introducción general «, in Orosio. Historias I-IV, Madrid, 1982, pp. 6-69.

M. SELIG, „Die Entwicklung des Determinantensystems in Spätlateinischen«, in W. Raible (ed.), Romanistik, Sprachtypologie und Universalienforschung. Beiträge zum Freiburger Romanistentag, Tübingen, 1989.

M. SeLIG, Die Entwicklung der Nominaldeterminanten im Spätlatein, Tübingen, 1992.

S. A. THOMPSON, »Modern English from a typological point of view: some implications of the function of word order«, Linguistische Berichte 54, 1978, pp. 19-35.

V. VäĀNÄNEN, Le Journal-Épître d'Égérie (Itinerarium Egeriae). Étude linguistique, Helsinki, 1987.

V. VÄÄNÄNEN, „I due livelli del linguaggio orale nell'Itinerarium Egeriae«, in Atti del Convegno internazionale sulla Peregrinatio Egeriae, Arezzo, 1990, pp. 159-65.

T. VENNEMANN, »An explanation of drift«, in Ch. N. Li (ed.), Word order and word order change, Austin, 1975, pp. 269-305.

A. ZAMBONI, "Cambiamento di lingua o cambiamento di sistema? Per un bilancio cronologico della Transizione«, in J. Herman (ed.), La transizione dal latino alle lingue romanze, Tübingen, 1998, pp. 99-127. 


\section{Povzetek}

\section{DOLOČNOSTNE STRATEGIJE V BESEDNEM REDU IN V EKSISTENCIALNO-LOKATIVNIH TER LOKATIVNIH ZVEZAH V POZNI LATINŠČINI}

V članku se preučujeta parametra, ki sta v pozni latinščini začenjala doživljati bistvene spremembe: izražanje določnosti in proces ustalitve besednega reda, ki je drugačen, kot je bil prej. Oba pojava se skušata obravnavati povezano. Namen takega načina dela je ugotoviti, ali ni morda v razvoju, v katerem so stavčni skladniki prešli iz prostega besednega reda $v$ nespremenljivega, eden izmed temeljnih dejavnikov ravno nastanek člena. V raziskavi se preverja, kako poteka več procesov, ki se v jeziku uporabljajo za zaznamovanje določnosti; med njimi so posebne pozornosti deležni "demonstrativi". Poleg tega se raziskuje besedni red temeljnih skladnikov, ki sestavljajo lokativne zveze, s ciljem zagotoviti ustrezne odnose med analiziranimi parametri. Vprašanje se obravnava tudi $z$ diahronega vidika, pri čemer služijo za vzorec izbrana poglavja iz Livija, Orozija in delo Peregrinatio Egeriae. Na podlagi diahrone obravnave moremo ugotoviti, da se ustalitev besednega reda ter pojav in razvoj člena nista izkazala za pojava, ki bi bila nujno soodvisna, čeprav $\checkmark$ nekaterih primerih ne moremo izključiti možnosti njune medsebojne povezanosti. 